\title{
The Effect of Activated Carbon Addition on Woody Cutting Waste Briquette Combustion Quality
}

\author{
Qurrotin Ayunina Maulida Okta Arifianti ${ }^{1, *}$, Ufafa Anggarini ${ }^{2}$, Akbar Nafis ${ }^{1}$, \\ Erny Rosita Sari ${ }^{1}$ and Elita Fidiya Nugrahani ${ }^{1}$ \\ ${ }^{1}$ Department of Engineering Management, Faculty of Industrial and Agroindusty Technology, \\ Universitas Internasional Semen Indonesia, Kompleks PT. Semen Indonesia (Persero) Tbk, \\ Jl. Veteran, Kb. Dalem, Sidomoro, Kebomas, Gresik 61122, East Java, Indonesia. \\ ${ }^{2}$ Department of Chemical Engineering, Faculty of Industrial and Agroindusty Technology, \\ Universitas Internasional Semen Indonesia, Kompleks PT. Semen Indonesia (Persero) Tbk, \\ Jl. Veteran, Kb. Dalem, Sidomoro, Kebomas, Gresik 61122, East Java, Indonesia.
}

\begin{abstract}
This study aims to increase the calorific value of woody cutting waste briquette by adding activated carbon. The previous experiments showed that the highest calorific value of woody cutting waste briquette reached only $3630 \mathrm{kCal} \mathrm{kg}^{-1}$. In this research, activated carbon was made of Palmyra palm fiber using $\mathrm{H}_{3} \mathrm{PO}_{4}$ as an activator solvent. There are four different proportion of activated carbon used in the experiment, for example, $5 \%, 10 \%, 15 \%$, and $20 \%$ with $10 \%$ tapioca flour binder. The woody cutting waste were carbonized and sieved into 50 mesh to 100 mesh. The briquette performance was tested using proximate analysis, bomb calorimeter, and combustion analysis. The addition of activated carbon in briquette could increase the calorific value from $3630 \mathrm{kCal} \mathrm{kg}^{-1}$ to around $4500 \mathrm{kCal} \mathrm{kg}^{-1}$.
\end{abstract}

Keywords: Activated carbon, briquette, calorific value, palmyra palm fiber, reactive, woody waste.

\section{Introduction}

Activated carbon is a type of carbon activated at a certain temperature to produce a high inner surface area and have complex pores. With these characteristics, activated carbon is very suitable for applications that require large contact areas, such as adsorption processes, reactions, catalysts and so on. Some literature shows that activated carbon is mostly applied as an absorber. According to [1] used a mixture of activated carbon and amendment charcoal to dissolve Polycyclic Aromatic Hydrocarbons (PAHs) in sewage sludge. The results showed that activated carbon and carbon were able to effectively reduce the concentration of water in PAH pores. Angin [2] created activated carbon from sour cherry plants (Prunus cerasus L.) to remove basic textile dyes.

\footnotetext{
*Corresponding author: qurrotin.arifianti@uisi.ac.id
} 
In addition to the absorption properties, activated carbon has a greater heating value compared to carbon charcoal. Carrier et al., [3] compared the characteristics of activated carbon and carbon charcoal made from sugarcane bagasse. The results of the comparison showed that activated carbon had a higher fixed carbon content than sugarcane bagasse char, which was $69 \%$. While sugar cane charcoal had a fixed carbon content of only $36.2 \%$. The higher the carbon content, the greater the calorific value. Chen et al., [4] utilizied activated carbon waste captured by air pollution regulators. The activated carbon was then washed using deionized water and mixed into organic sludge fuel. The results showed that there was a significant increase in heat value and carbon content in the fuel when residual activated carbon was added. The highest heating value that could be achieved is $4515 \mathrm{kCal} \mathrm{kg}^{-1}$. In addition, other studies showed that the calorific value of unburned carbon in activated carbon waste was more than $4000 \mathrm{kCal} \mathrm{kg}^{-1}$, thus activated carbon had the potential to be used as an alternative fuel [5].

The aim of this present study was to increase the calorific value of woody cutting waste briquette by adding activated carbon. The previous experiments showed that the highest calorific value reaches only $3630 \mathrm{kCal} \mathrm{kg}^{-1}$. In this research, activated carbon was made of palmyra palm fiber using $\mathrm{H}_{3} \mathrm{PO}_{4}$ as an activator solvent. $\mathrm{H}_{3} \mathrm{PO}_{4}$ was chosen since it was able to produce higher area than $\mathrm{NaOH}$ and $\mathrm{KOH}$ solvent based on the earlier experiment. The surface area of activated carbon produced by $\mathrm{H}_{3} \mathrm{PO}_{4}$ solvent is $373.5675 \mathrm{~m}^{2} \mathrm{~g}^{-1}$. Meanwhile, $\mathrm{NaOH}$ and $\mathrm{KOH}$ solvent resulted area of $33.87878 \mathrm{~m}^{2} \mathrm{~g}^{-1}$ and $218.8230 \mathrm{~m}^{2} \mathrm{~g}^{-1}$, respectively. There are four different proportion of activated carbon used in the experiment, for example, $5 \%, 10 \%, 15 \%$, and $20 \%$ with $10 \%$ tapioca flour binder. The woody cutting waste were carbonized and sieved into 50 mesh to 100 mesh. The briquette performance were tested using proximate analysis, bomb calorimeter, and combustion analysis.

\section{Methodology}

\subsection{Preparation of raw materials and activated carbon production}

As aforementioned, the main purpose of this research is to increase the existing briquette quality by adding activated carbon in some various of percentage. The raw material used to produce activated carbon was Palmyra palm fiber (as can be seen in Figure 1). The fiber was collected and dried naturally under the sun and also in the oven to facilitate the carbonization process. The carbonization process was carried out by burning it in the reactor with a temperature of around $400{ }^{\circ} \mathrm{C}$ to $500{ }^{\circ} \mathrm{C}$. The charcoal produced from this process was then sieved to a size of 50 mesh to 100 mesh.

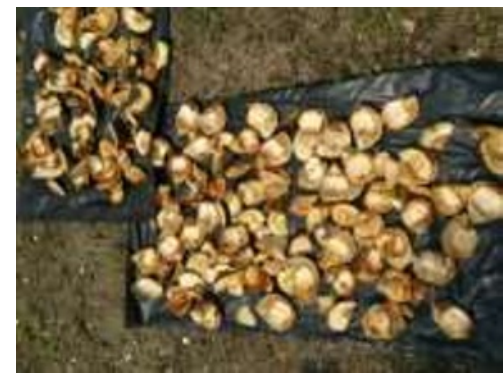

Fig. 1. Palmyra palm fiber waste. 


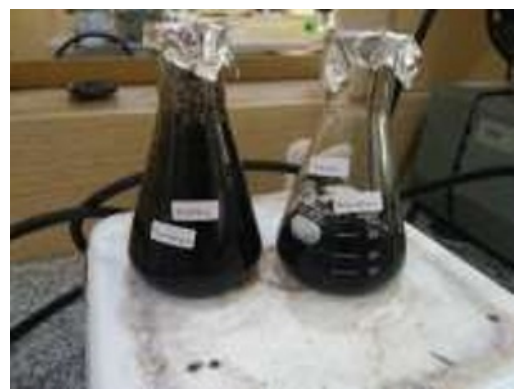

Fig. 2. Activation process.

The next step, the charcoal was impregnated with $30 \%$ of $\mathrm{NaOH}$ in a stirrer for $24 \mathrm{~h}$. $\mathrm{NaOH}$ saturated raw materials before it was activated. Subsequently, it was filtered using distilled water until the $\mathrm{pH}$ reached 7 and dried using an oven at a temperature of $105{ }^{\circ} \mathrm{C}$ for $1 \mathrm{~h}$ which aimed to eliminate the $\mathrm{NaOH}$ content left in the ingredients. Activated carbon process was performed by adding $\mathrm{H}_{3} \mathrm{PO}_{4}$ over $24 \mathrm{~h}$ to create pores. Figure 2 shows the process of activated carbon. Then the material was rewashed and dried at $105{ }^{\circ} \mathrm{C}$. Eventually, the activated carbon was heated at $300{ }^{\circ} \mathrm{C}$ to remove the remaining content

\subsection{Briquette production}

The woody waste char was crushed up to 50 mesh to 100 mesh using pulvurizer mill. There was four variation of mixture which the detailed could be seen in Table 1 . The binder percentage was made of tapioca starch. The adhesive percentage was chosen as $10 \%$ since it had great performance based on various literatures. The briquette geometry was $3.5 \mathrm{~cm} \times$ $3 \mathrm{~cm}$ (diameter $\times$ height). The molding process used a briquetting hydraulic press (BHP), with two tons power. The next step was drying the briquette in the oven to evaporate the water content. Figure 3 the prototype of briquettes.

Table 1. Distribution of composition for each variation

\begin{tabular}{|l|l|l|l|}
\hline No & $\begin{array}{c}\text { Charcoal } \\
\text { percentage }\end{array}$ & $\begin{array}{c}\text { Activated carbon } \\
\text { percentage }\end{array}$ & \multicolumn{1}{|c|}{$\begin{array}{c}\text { Adhesives } \\
\text { percentage }\end{array}$} \\
\hline 1 & $85 \%$ & $5 \%$ & $10 \%$ \\
\hline 2 & $80 \%$ & $10 \%$ & $10 \%$ \\
\hline 3 & $75 \%$ & $15 \%$ & $10 \%$ \\
\hline 4 & $70 \%$ & $20 \%$ & $10 \%$ \\
\hline
\end{tabular}

Fig. 3. Briquettes prototype

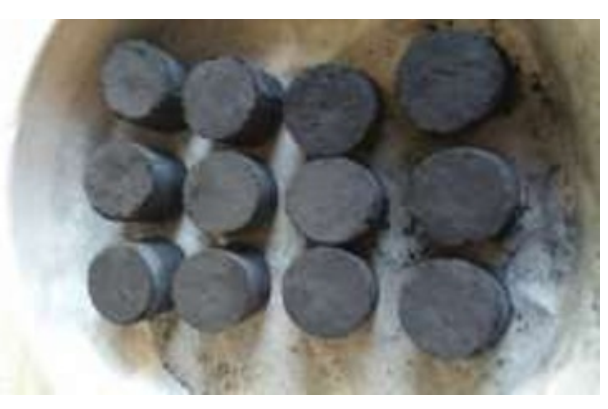


Three types of test conducted in this research consist of proximate test, combustion test, and bomb calorimeter test. Physics characteristics comprising moisture content, ash content, volatile matter, and fixed carbon content as well as calorific value were examined in Tekmira Bandung. The test output was compared to Indonesian National Standard (SNI). As shown in Figure 4, to perform combustion test, the plate was heated for around two minutes. The briquette then was put on the hot plate and the initial ignition time was observed until ember appeared. Infrared thermometer was used to monitor the temperature distribution of the briquettes for every one minute. The duration of combustion process was accounted until the briquette altered to ash. This procedure was replied three times. Table 2 shows the design of experiment.

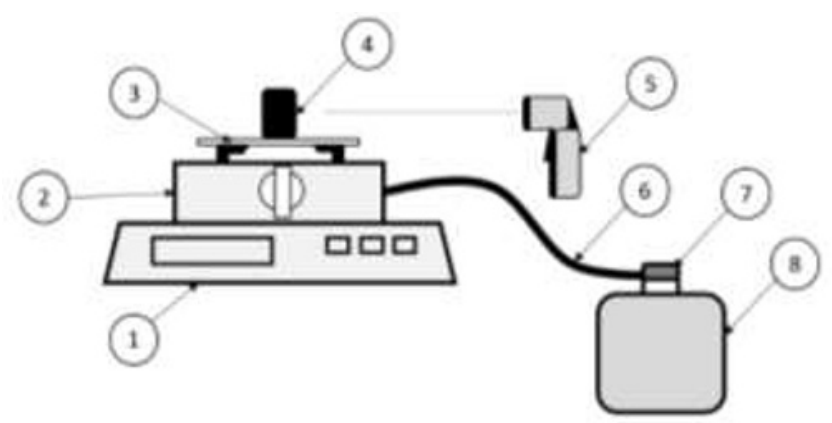

Fig. 4. Installation Scheme for Combustion Test (1): digital balance; (2): portable gas stove; (3): iron sheet; (4): briquette; (5): infrared thermometer; (6): gas hose; (7): regulator;

(8): gas holder).

Table 2. Design of Experiment

\begin{tabular}{|c|c|c|}
\hline \multicolumn{2}{|c|}{ Input data } & Output data \\
\hline Constant variable & Independent variable & Measured data \\
\hline $\begin{array}{ll}\text { - } & \text { Briquette } \\
& \text { Dimension } \\
\text { - } & \text { Raw Material and } \\
& \text { Briquette Mass } \\
\text { - } & \text { Briquette Drying } \\
& \text { Temperature } \\
-\quad & \text { Ratio of tapioca } \\
& \text { flour and water }\end{array}$ & $\begin{array}{l}\text { Ratio between } \\
\text { activated } \\
\text { carbon and } \\
\text { woody cutting } \\
\text { waste char }\end{array}$ & $\begin{array}{ll}\text { - } & \text { Physic } \\
& \text { Characteristics } \\
\text { - } & \text { Inial Ignition Time } \\
\text { - } & \text { Combustion } \\
& \text { Temperature } \\
\text { - } & \text { Briquette Mass } \\
& \text { Difference During } \\
& \text { Combustion Process } \\
\text { - } & \text { Calorific Value } \\
\end{array}$ \\
\hline
\end{tabular}

\section{Results and discussion}

\subsection{Proximate test}

Figure 5 shows the proximate test results. It contains the information about the physic characteristics of briquette with and without adding activated carbon The moisture content of the briquette combined with activated carbon stood around $5 \%$. These value were under the Indonesia National Standard which the maximum limit is $8 \%$. Ash content increased slowly over the activated carbon percentage. $5 \%$ of activated carbon in briquette possed $23.03 \%$, which was the lowest ash content among the variation. Meanwhile, the highest ash content was found in $20 \%$ activated carbon variation and reached up to $24.31 \%$. Compare to the briquette contained pure woody waste char, it was obtained that the activated carbon briquette had lower ash content. It was true since mostly in the briquette 
without activated carbon addition was made of twigs and leaves which tended to produce higher ash content [7]. According to [8], leaves contained the highest silica content.
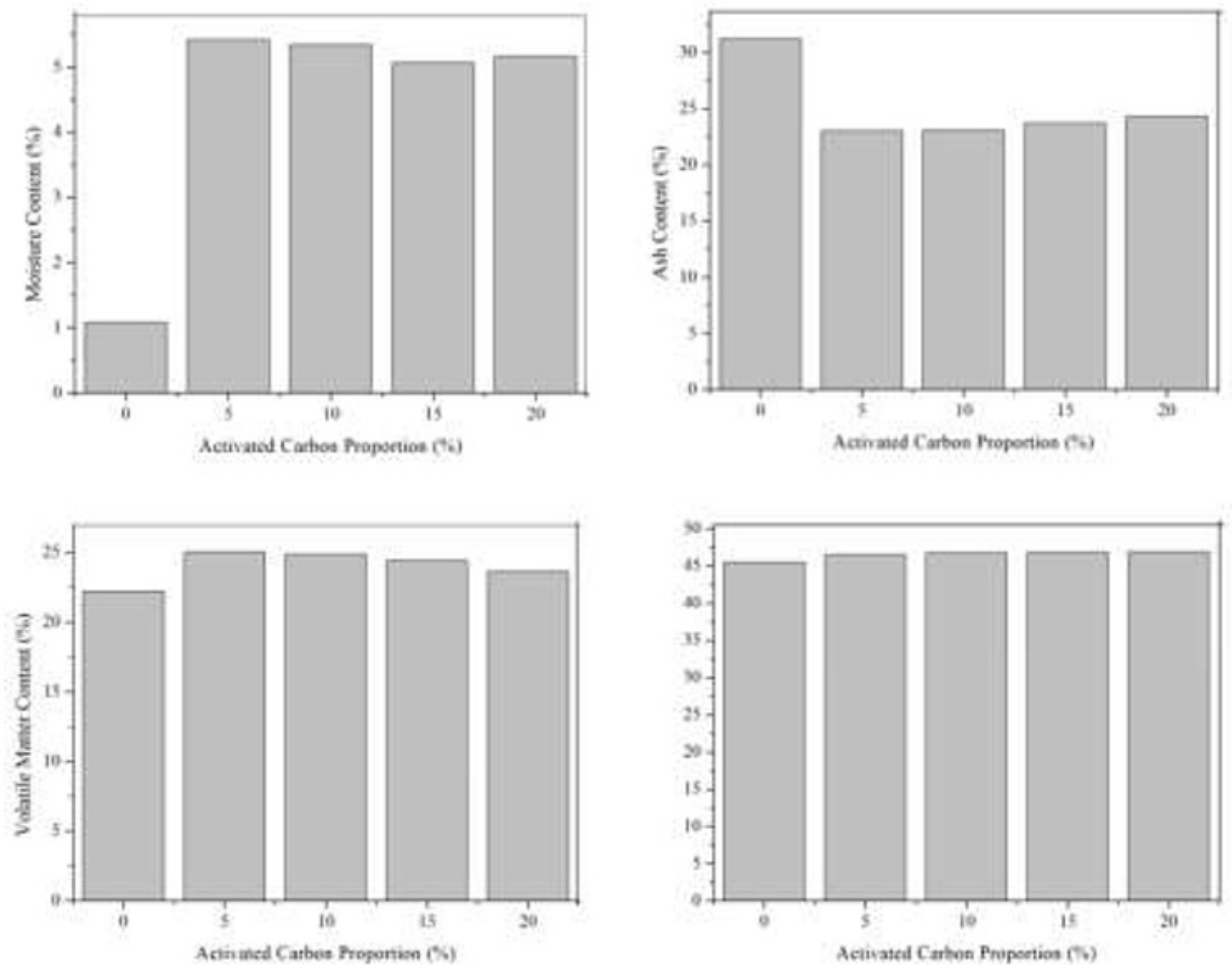

Fig. 5. Proximate analysis results.
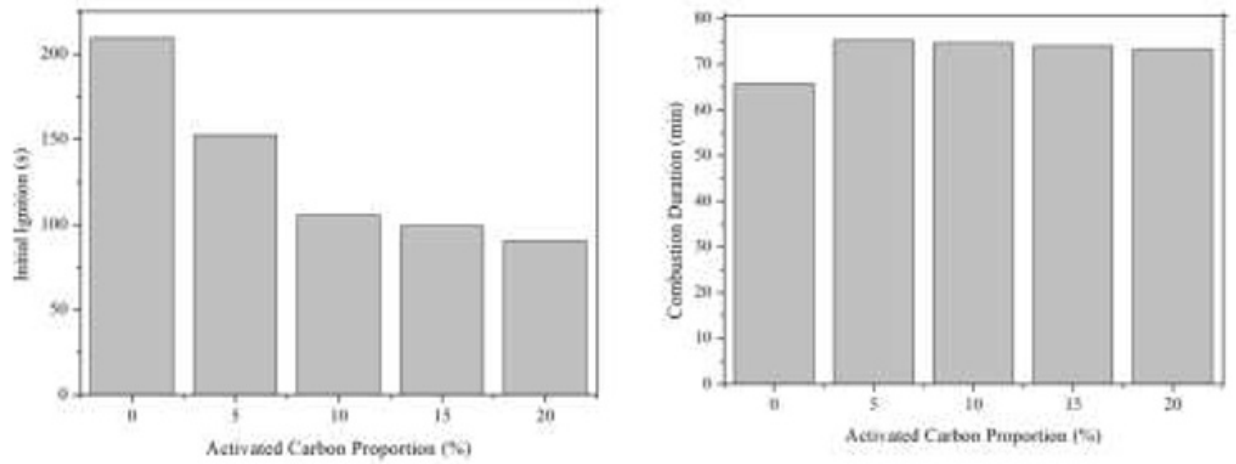

Fig. 6. Combustion test result (a: Initial ignition time; b: Combustion duration) 


\subsection{Combustion Characteristics}

As shown in Figure 6Fig. 6. Combustion test result (a: Initial ignition time; b: Combustion duration), $20 \%$ of activated carbon percentage had the shortest initial ignition time, while there was the longest initial ignition time in the briquette with $0 \%$ activated carbon. It occured since activated carbon had a wider area. Therefore, this briquette containing more activated carbon could be ignited more rapidly. Figure 6 also illustrates the duration of combustion process. $0 \%$ of activated carbon briquette had the shortest combustion time period. The main reason is due to the lowest moisture content among other types.

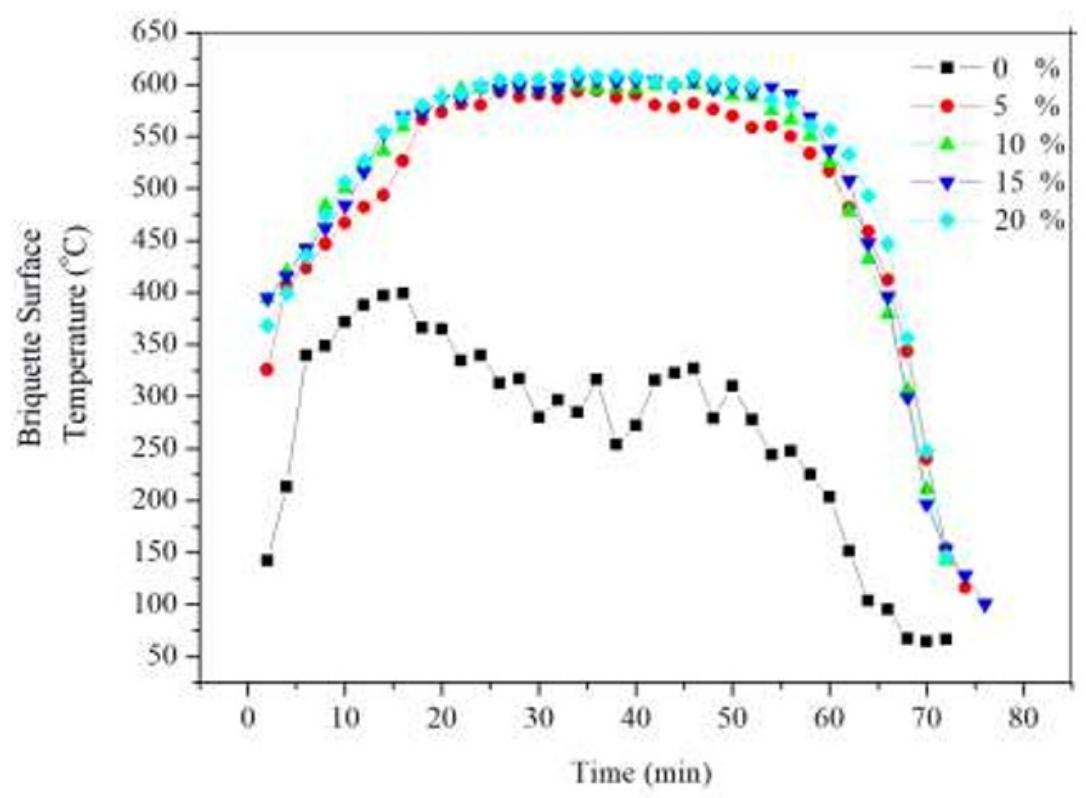

Fig. 7. Temperature distribution on briquette surface on combustion test with variation of activated carbon

Figure 7 provides the information about the temperature distribution during the combustion process. There was a significant temperature difference between briquette with and without activated carbon. The highest temperature of briquette with $0 \%$ activated carbon was only $452{ }^{\circ} \mathrm{C}$. Meawhile, briquette with activated carbon almost reached $620{ }^{\circ} \mathrm{C}$. Based on the result [9], the biochar containing a lower fixed carbon causes a modest temperature. The highest fixed carbon was around $60 \%$ and the combustion temperatur could reach approximately $600{ }^{\circ} \mathrm{C}$.

\subsection{Calorific value}

Based on the Table 3, the addition of activated carbon in briquette could increase the calorific value from $3630 \mathrm{kCal} \mathrm{kg}^{-1}$ to around $4500 \mathrm{kCal} \mathrm{kg}^{-1}$. Moreover, the higher content of activated carbon, the calorific value was also greater. The obtained result was similar to other findings. The briquette with greater fixed carbon content was prone to produce higher calorific value $[10,11]$. 
Table 3. Calorific value of each variation

\begin{tabular}{|c|c|c|}
\hline No & Variation & $\begin{array}{c}\text { Result } \\
\left(\mathrm{kCal} \mathrm{kg}^{-1}\right)\end{array}$ \\
\hline 1 & $0 \%$ & 3630 \\
\hline 2 & $5 \%$ & 4578 \\
\hline 3 & $10 \%$ & 4592 \\
\hline 4 & $15 \%$ & 4577 \\
\hline 5 & $20 \%$ & 4528 \\
\hline
\end{tabular}

\section{Conclusion}

The addition of activated carbon in briquette could increase the calorific value from $3630 \mathrm{kCal} \mathrm{kg}^{-1}$ to around $4500 \mathrm{kCal} \mathrm{kg}^{-1}$. However, the activated carbon briquette still could not meet the Indonesian National Standard, especially related to ash content, fixed carbon, and calorific value.

This work was funded by LPPM UISI in 2019 through Hibah Riset Terapan scheme with number: 04/KP.03/03-01.03.01/03.19. The title of the research is Karakteristik Briket Sampah Organik UISI dengan Variasi Penambahan Arang dan Karbon Aktif Siwalan.

\section{References}

1. W.S. Chen, F.C. Chang, Y.H. Shen, M.S. Tsai, Bioresour. Technol., 102:54065410(2011).

https://www.sciencedirect.com/science/article/pii/S0960852410018092

2. W.T. Tsai, J.H. Chang, K.J. Hsien, Y.M Chang, Bioresour. Technol., vol. 100, pp. 406-412(2009).

https://www.sciencedirect.com/science/article/pii/S0960852408005336

3. Y. Yuliah, M. Kartawidjaja, S. Suryaningsih, K. Ulfi, Fabrication and characterization of rice husk and coconut shell charcoal based bio-briquettes as alternative energy source. IOP Conf. Ser. Earth Environ. Sci, 65:1-8(2017). https://iopscience.iop.org/article/10.1088/1755-1315/65/1/012021/meta

4. A. Enders, K. Hanley, T. Whitman, S. Joseph, J. Lehmann, Bioresour. Technol., 114:644-653(2012). https://www.sciencedirect.com/science/article/pii/S0960852412004403

5. K. Kasmira, L. Lahming, R. Fadilah, Jurnal Pendidikan Teknologi Pertanian, 4:4955(2018). [in Bahasa Indonesia]. https://ojs.unm.ac.id/ptp/article/view/6232

6. P. Oleszczuk, S.E. Hale, J. Lehmann, G. Cornelissen, Bioresour. Technol., 111:, 8491(2012). https://www.sciencedirect.com/science/article/pii/S0960852412002593

7. D. Angin, Bioresour. Technol., 168:259-266(2014). https://www.sciencedirect.com/science/article/pii/S0960852414002715

8. M. Carrier, A.G. Hardie, Ü. Uras, J. Görgens, J.H. Knoetze, J. Anal. Appl. Pyrolysis, 96:24-32(2012).

https://www.sciencedirect.com/science/article/pii/S016523701200037X

9. Agriculture Organization of the United Nations, Simple technologies for charcoal making, Forestry Dept and Agriculture Organization of the United Nations: 
Mechanical Wood Products BranchFood \& Agriculture Org. (1983). https://books.google.co.id/books?id=Ww-hfFDy1WYC\&dq

10. T.P. Ding, J.X. Zhou, D.F. Wan, Z.Y. Chen, C.Y. Wang, F. Zhang, Geochimica et Cosmochimica Acta, 72,5:1381-1395(2008).

https://www.sciencedirect.com/science/article/pii/S0016703708000276

11. W. Nuriana, N. Anisa, Energy Procedia, 47,295-302(2014).

https://www.sciencedirect.com/science/article/pii/S1876610214002446 